WALDEMAR W. ŻUREK

\title{
„FELIX CULPA” PRYMASA POLSKI AUGUSTA HLONDA?
}

Kardynał August Hlond zasługuje bez wątpienia na miano męża stanu w rozumieniu powszechnie przyjętym, a w szczególności za hierarchę Kościoła katolickiego o wymiarze wykraczającym poza obszar jego pasterzowania - Polskę. Kościołowi polskiemu przewodził od 1926 r. do swej śmierci w 1948 r. Był primus inter pares $^{1}$, a prerogatywy kanoniczne, jakie posiadał, wynikały z dwóch źródeł: historycznego, był bowiem legatus natus ${ }^{2}$, która to godność wiązała się z prymasowstwem od 15 lipca 1515 r., oraz ze specjalnych uprawnień od Stolicy Apostolskiej przyznawanych prymasom, co nie równało się prerogatywom jurysdykcyjnym w stosunku do poszczególnych diecezji. Z chwilą zawarcia konkordatu w $1925 \mathrm{r}$. ich znaczenie było ograniczone, gdyż sprawy natury ogólnokościelnej należały od tego momentu do nuncjusza.

W czasie drugiej wojny światowej kardynał Hlond przebywał za granicą, gdzie w miarę możliwości zabiegał nie tylko o sprawy kościelne w okupowanej Polsce, ale także angażował się w wymiarze międzynarodowym w działalności na rzecz okupowanego kraju. Sprawa wyjazdu kardynała Hlonda we wrześniu 1939 r. z kraju była, a może także w dalszym ciągu pozostaje przedmiotem krytyki, której tezą jest oskarżenie o opuszczenie Kościoła polskiego ze względu na swe bezpieczeństwo, co jednak nie polega na prawdzie, bowiem kardynał Hlond jechał do Rzymu w interesie Polski i na życzenie jej rządu. Hlond powrócił do Polski 20 lipca

Ks. dr hab. Waldemar W. Żurek SDB, prof. KUL - Ośrodek Archiwów, Bibliotek i Muzeów Kościelnych na Katolickim Uniwersytecie Lubelskim Jana Pawła II; e-mail: zurek@kul.pl. ORCID: https://orcid.org/0000-0002-5602-5077.

1 Primus inter pares (łac. ,„pierwszy wśród równych sobie”). Tak określa się osobę, która posiada autorytet wśród pozostałych członków grupy, do której należy, jednak nie wiąże się on z żadnymi specjalnymi przywilejami.

2 Legatus natus - to tytuł przyznawany przez papieża biskupom niektórych diecezji lub katolickim władcom niektórych państw. Posiadanie tego tytułu łączyło się z pewnymi uprawnieniami jurysdykcyjnymi i prerogatywami honorowymi. Obecnie tytuł honorowy. 
1945 r. Także pewna zwłoka w podjęciu decyzji o powrocie budziła refleksje nie zawsze dla kardynała życzliwe. Zwłoka ta jest zrozumiała, gdyż sytuacja polityczna w Polsce była o tyle jasna, że bezdyskusyjna była dominacja w niej Związku Sowieckiego i znano też postanowienia jałtańskie, natomiast dopiero w dwa dni po powrocie Hlonda ogłoszono Manifest PKWN³, co zresztą miało znaczenie raczej formalne, gdyż jego postanowienia tylko w części weszły w życie. Co się tyczy ustroju i porządku publicznego, pozostały na papierze. $\mathrm{O}$ ile granica państwa polskiego na wschodzie była faktem dokonanym, o tyle zachodnia zależała stale jeszcze od postanowień mocarstw zwycięskich w wojnie z Niemcami. Konferencja Poczdamska obradująca w dniach 17 lipca - 2 sierpnia 1945 r. podjęła decyzję $\mathrm{w}$ sprawie polskiej granicy zachodniej. Memorandum zgłoszone przez Tymczasowy Rząd Jedności Narodowej w Poczdamie było raczej czystą formalnością, bowiem decyzję w tej sprawie podjął Stalin przy wymuszonej raczej aprobacie aliantów zachodnich. Od początku więc przynależność tzw. Ziem Odzyskanych do Polski była warunkowana rezygnacją Polski z suwerenności na rzecz dominacji sowieckiej. Wychodząc nieco chronologicznie o dwa dziesięciolecia do przodu, wystarczy dobrze przeanalizować przemówienia Władysława Gomułki, z których nieustannie wiało obawą, że parasol sowiecki nad terytorium Polski na północy i zachodzie może się zamknąć pod wpływem jakichkolwiek przejawów niechęci Polaków do Związku Sowieckiego. Było to zagrożenie o tyle bardziej realne, że Niemiecka Republika Demokratyczna stanowiła o wiele solidniejszy niż Polska bastion dla sowieckiego panowania.

Trudno obecnie wczuć się w tok myślenia kardynała Augusta Hlonda, który na terenie Polski znalazł się w momencie, kiedy miały się decydować losy jej granic, ustroju (przynajmniej formalnie), a przede wszystkim mocno poszczerbionego przez wojnę i okupację Kościoła. Połączenie Gniezna z Warszawą było pociągnięciem o wielkim znaczeniu. Prymas Hlond zgodnie z tradycją polską przykładał wagę do bezpośrednich kontaktów z rządem. Pamiętać należy, że ten rząd zdecydowanie zdominowany przez komunistów typu sowieckiego, przynajmniej do wyborów 1947 r., a więc od powrotu Hlonda przez około półtora roku stwarzał

3 Manifest Polskiego Komitetu Wyzwolenia Narodowego (tzw. manifest lipcowy) - odezwa do narodu polskiego ogłoszona z datą 22 lipca 1944 r., z podaniem miasta Chełma, jako miejsca ogłoszenia. Faktycznie został podpisany i zatwierdzony przez Józefa Stalina w Moskwie 20 lipca 1944 r. i tam również ogłoszony, a nie w Chełmie. Określał zasady ustrojowe przyszłego państwa polskiego. Za pomocą manifestu usiłowano pozyskać zwolenników nowej władzy w Polsce. Mówił o demokracji, równości i wolności - czyli adaptacji na gruncie polskim sowieckich wzorów ustrojowych, społecznych i gospodarczych. Uzasadniał rozprawę z polskim państwem podziemnym, zapowiadał oczekiwaną reformę rolną. Manifest traktowany był przez komunistów jako fundamentalny dokument i szybko stał się jednym z elementów mitu początku Polskiej Rzeczpospolitej Ludowej. 
pozory kontynuacji państwowości przedwrześniowej. Reformy równocześnie podejmowane motywowane były frazeologią demokratyczną. Przy tym szeroki ogół nie orientował się, o jaką demokrację tu chodziło, a więc, że ma to być demokracja socjalistyczna, niemająca z klasycznym znaczeniem tego pojęcia nic wspólnego. Kościół w tym czasie ucierpiał wskutek reformy rolnej, ale poważniejszym ostrzeżeniem było wypowiedzenie 12 września 1945 r. konkordatu. Dla kardynała Hlonda oznaczało to konieczność podejmowania decyzji bez współdziałania ze Stolicą Apostolską, gdyż od samego początku władze państwowe pilnie strzegły izolacji Polski w stosunku do Zachodu. Jednakże wiele wskazywało na to, że kardynał Hlond nie liczył się z długowiecznością władzy komunistycznej w Polsce, co z kolei zgadzało się z nastrojami, jakie panowały w społeczeństwie, a także w atmosferze politycznej świata powojennego, którego ambicję urządzania przejawiał wyraźnie Stalin - faktycznie bezapelacyjny zwycięzca w wojnie na terenie Europy.

Naszkicowane tu okoliczności przynajmniej w przybliżeniu uzmysławiają istotne cele działania kardynała Hlonda, niecierpiące najmniejszej nawet zwłoki. To, że prymas Hlond wracał z Rzymu ze specjalnymi uprawnieniami w stosunku do całego Kościoła polskiego, nie ulega wątpliwości. Przecież faktem dokonanym było odcięcie od Polski dwóch metropolii: Lwowa i Wilna, diecezji pińskiej oraz łuckiej. Z tej ostatniej nawet skrawek nie ostał się przy Polsce. Dokonanie regulacji na tym terenie nie było wszakże ani pilne, ani ze względów politycznych łatwe, bowiem Sowietom nie zależało na kontynuowaniu administracji kościelnej z terenów przez nich anektowanych, co podtrzymywałoby tradycję dla Kremla ogromnie niewygodną.

Nie wiadomo, w jakim stopniu kardynał Hlond liczył się z zastosowaniem w jałtańskiej Polsce polityki antyreligijnej i antykościelnej wypracowanej i praktykowanej w Sowietach? O komunizmie miał jednak pojęcie wyzbyte ze złudzeń. O ile w starych diecezjach polskich trzeba było leczyć rany zadane przez wojnę i okupację, a zerwanie konkordatu tylko w nieznacznym stopniu dawało się we znaki, to sytuacja na tzw. Ziemiach Odzyskanych stanowiła problem mający potrójne odbicie: w Stolicy Apostolskiej, w Polsce i w hierarchii niemieckiej jeszcze obecnej na tych terenach. Szerokie pole do popisu miały tu jednak władze polskie, mogące traktować w wymiarze kościelnym te tereny jako swoistą ziemię niczyją.

${ }^{4}$ PKWN zwrócił Kościołowi katolickiemu i innym związkom wyznaniowym utraconą przez nie w czasie okupacji własność. Na życzenie Józefa Stalina, potwierdzone przez Wandę Wasilewską, spod działania dekretu PKWN o reformie rolnej z 6 września 1944 r. wyłączone zostały dobra martwej ręki, należące do Kościoła i związków wyznaniowych. Nieruchomości ziemskie związków wyznaniowych, w tym należące do Kościoła katolickiego zostały znacjonalizowane ustawą z dnia 20 marca 1950 r. o przejęciu przez państwo dóbr martwej ręki, w zamian (rekompensata) za poręczenie proboszczom posiadania gospodarstw rolnych i utworzenie Funduszu Kościelnego. 
To był wprost wymarzony przypadek, pozwalający na kilka wersji polityki wobec Kościoła na tzw. Ziemiach Odzyskanych. Albo polegającej na ograniczaniu polskiej inicjatywy kościelnej po pozbyciu się katolików niemieckich, co w dalszej perspektywie umożliwiłoby stworzenie obszarów wyjętych spod wpływu Kościoła, albo dopuszczenie wprawdzie polskiej organizacji kościelnej, ale całkowicie sobie podporządkowanej, czego próby w 1950 r. rzeczywiście podejmowano ${ }^{5}$.

Hlond, prawdopodobnie w bezpośredniej rozmowie z papieżem Piusem XII ${ }^{6}$, a z całą pewnością z prosekretarzem stanu Domenico Tardinim ${ }^{7}$, przedstawił swe prognozy odnośnie do polityki komunistów wobec Kościoła na terenie o tak silnych wpływach kościelnych, jak Polska. Przyznanie Polsce ziem niemieckich, wprawdzie początkowo w nieokreślonym wymiarze, było wtedy także pewnikiem. Dla Hlonda, który z Niemcami nie miał dobrych doświadczeń, jasne było, iż na

5 B. Kumor, Historia Kościoła, część 8: Czasy współczesne 1914-1992, Lublin 1996, s. 481.

${ }^{6}$ Pius XII (Eugenio Pacelli, 1876-1939) - papież. W 1894 r. wstąpił do seminarium duchownego, od 1899 r. studiował prawo na Gregorianum. W 1899 r. przyjął święcenia kapłańskie. W 1902 r. uzyskał doktorat obojga praw i podjął praktykę w Sekretariacie Stanu Stolicy Apostolskiej. W 1911 r. podjął pracę w Kongregacji dla Nadzwyczajnych Spraw Kościelnych: podsekretarz, prosekretarz, sekretarz. Na początku kwietnia 1917 r. został nuncjuszem w Monachium. Bezskutecznie usiłował uzyskać informację o niemieckich planach wojennych. Organizował wsparcie dla ofiar pierwszej wojny światowej. W 1919 r. został mianowany nuncjuszem w Republice Weimarskiej, a w połowie lipca 1925 r. przeniósł siedzibę nuncjatury do Berlina. Czynił starania o poprawę sytuacji katolików w Rosji. W grudniu 1929 r. został mianowany kardynałem, a w lutym następnego roku sekretarzem stanu Stolicy Apostolskiej. W 1939 r. został wybrany na papieża. Ostrzegał Benito Mussoliniego przed konsekwencjami wojny. Nie akceptował nazizmu jako sojusznika w walce z bolszewizmem. Krytykowany był przez polską hierarchię kościelną za powierzenie biskupowi Splettowi z Gdańska tymczasowej administracji na części ziem wcielonych do Rzeszy, gdy prawowitym ordynariuszem diecezji płockiej był abp Antoni Julian Nowowiejski. Nieformalność tych aktów papieża podyktowana był troską o życie religijne wiernych. Podejmował możliwe działania na rzecz pomocy i ratowania Żydów. Odrzucał argumentację rządu polskiego, jakoby mianowanie biskupa Spletta administratorem diecezji chełmińskiej spowodowało przez rząd komunistyczny w Polsce zerwaniem konkordatu. Był wielkim dobroczyńcą Żydów i okazywał sympatię katolikom niemieckim. Z. ZIELIŃski, Papieże i papiestwo dwóch ostatnich wieków 1775-1978, Warszawa 1983, s. 480-522.

7 Kardynał Domenico Tardini (1888-1961) - urzędnik Kurii Rzymskiej, kardynał i sekretarz Stanu Stolicy Apostolskiej. Święcenia kapłańskie przyjął w 1912 r. W 1921 r. rozpoczął pracę w Kurii Rzymskiej. Pracował w Kongregacji Nadzwyczajnych Spraw Kościoła, był asystentem Akcji Katolickiej (1923-1929), od 1935 r. rozpoczął pracę w Sekretariacie Stanu, dochodząc za pontyfikatu Piusa XII do funkcji prosekretarza Stanu, gdyż funkcję sekretarza Stanu do śmierci sam papież sprawował. Dopiero papież Jan XIII ogłosił Tardiniego sekretarzem Stanu i mianował go kardynałem. Tardini był zaangażowany w prace przygotowawcze do Soboru Watykańskiego II poprzez rozesłanie ankiety do biskupów świata, aby przedstawili najważniejsze problemy, które winny być poddane pod dyskusję ojców soboru. Zmarł w Viterbo nie doczekawszy się początku obrad. C.F. CASULA, Domenico Tardini 1888-1961, Roma 1988. 
ziemiach poniemieckich nie może ostać się niemiecka administracja kościelna. $\mathrm{Z}$ kolei papież i kuria mogły mieć co do tego odrębne przekonania. W praktyce kościelnej likwidacja i powoływanie nowych diecezji należały wyłącznie do Stolicy Apostolskiej, podobnie jak ustanawianie władzy hierarchicznej. Kuria nie uznawała pośpiechu, toteż nagłością chwili nie mógł Hlond tłumaczyć podejmowanych przez siebie decyzji. Jakiekolwiek by one nie były, musiały mieć placet papieża. Takich pełnomocnictw Watykan raczej nie udzielał. Hlond wszakże miał znane już pełnomocnictwa do podejmowania decyzji w Polsce, także na nowych przyznanych jej ziemiach niemieckich. Ale znowu trzeba tu brać wzgląd na normy kanoniczne, obowiązujące w każdej sytuacji z tym tak ważnym w kanonistyce „nisi”, tzn. jeśli najwyższa władza kościelna nie postanowi inaczej. Można zakładać, że te normy miały mieć zastosowanie w zgodzie z udzielonymi Hlondowi pełnomocnictwami. Decyzje kardynała Honda winny być zatem podejmowane z uwzględnieniem niemieckich władz kościelnych obecnych na odnośnym terenie. Czy można uznać, że Hlond działał w zgodzie z tymi zasadami? Skłonił wszakże administratora diecezji wrocławskiej, ks. Ferdynanda Piontka ${ }^{8}$ do rezygnacji z zajmowanego urzędu. Podobnie uczynił z biskupem Maksymilianem Kallerem ${ }^{9}$ na Warmii. Wikariusz apostolski Wolnej Prałatury Pilskiej Johannes Bleske, a także biskup gdański Karl Maria Splett ${ }^{10}$, po swoim aresztowaniu, również zrzekli się stanowisk. Pod

8 Ksiądz Ferdynand Piontek (1879-1963) - niemiecki duchowny katolicki, wikariusz kapitulny archidiecezji wrocławskiej. Urodził się w Głubczycach. Po śmierci kard. Adolfa Bertrama (6 lipca 1945) wybrany został na wikariusza kapitulnego archidiecezji wrocławskiej. Po przejęciu archidiecezji przez polskich administratorów, wyjechał w 1946 r. do Niemiec Zachodnich. W 1947 r. przybył do Görlitz i jako administrator objął rządy w pozostałej części archidiecezji wrocławskiej. W maju 1959 r. został mianowany biskupem z siedzibą w Görlitz. Pochowany przy kościele św. Jakuba w tym mieście. B. SNOCH, Górnoślaski leksykon biograficzny. Suplement do wydania drugiego, Katowice 2006, s. 89.

9 Biskup Maxymilian Kaller (1880-1947) - działacz katolicki, biskup warmiński. Urodził się w Bytomiu. Studia teologiczne odbył na Uniwersytecie Wrocławskim. Święcenia kapłańskie przyjął w 1903 r. W 1926 r. mianowany został administratorem apostolskim w Pile, a po utworzeniu w 1929 r. prałatury niezależnej otrzymał godność prałata, gdzie dążył do likwidacji parafii polskich na terenie prałatury pilskiej. W 1930 r. otrzymał nominację na biskupa warmińskiego. Krytykował antykościelną politykę rządu niemieckiego. Organizował duszpasterstwo dla ludności niemieckiej osiedlanej w miejsce deportowanych Polaków. W 1945 r. został wywieziony z Warmii przez gestapo, dokąd wkrótce powrócił. W tym roku na prośbę kard. Hlonda zrzekł się jurysdykcji nad częścią diecezji warmińskiej w granicach Polski. W roku następnym Pius XII mianował go pełnomocnikiem ds. przesiedleńców niemieckich. Zmarł we Frankfurcie n. Menem. E. Gigilewicz, Kaller Maxymilian bp, w: Encyklopedia Katolicka, t. VIII, Lublin 2000, kol. 406-407.

10 Biskup Karol Maria Splett (1989-1964) - urodził się w Sopocie. Studia teologiczne ukończył w Pelplinie. Święcenia kapłańskie przyjął w 1921 r. Studia prawnicze odbył w Rzymie, gdzie w 1923 r. uzyskał doktorat. W czerwcu 1938 r. Pius XI mianował go biskupem gdańskim. Wyrażał 
tym względem kardynał Hlond miał wolną rękę. Jedyna niedogodność, to brak odpowiedzi biskupa Berlina, hrabiego Konrada von Preysinga ${ }^{11}$, na prośbę Hlonda o jurysdykcję nad skrawkiem diecezji berlińskiej w granicach Polski. Można było to poczytać jako akt sprzeciwu w stosunku do tego, co Hlond robił na terenach Ziem Odzyskanych.

Zaprowadzenie hierarchii polskiej w miejsce niemieckiej postrzegane było w Niemczech i częściowo też w Watykanie jako bezprawie. Pierwszym duchownym niemieckim, który w sposób dramatyczny i z pewną przesadą zrelacjonował w Rzymie wydarzenia we Wrocławiu w 1945 r. był kapłan wrocławski, Johannes Kaps, radca konsystorza we Wrocławiu, który w sierpniu 1945 r. wraz z ks. Ferdynandem Piontkiem dostał się do Rzymu ${ }^{12}$. Lobby niemieckie w Rzymie skupione w Kurii i w niemieckim instytucie historycznym na Campo Santo Teutonico wsparte relacją Kapsa odegrało niewątpliwie istotną rolę w oddziaływaniu na Piusa XII, mającym na celu zdezawuowanie poczynań Hlonda. Relacje Kapsa spowodowały interwencję Stolicy Apostolskiej u kardynała Hlonda, być może nie tyle z powodu wprowadzenia przez Prymasa polskiej administracji kościelnej, ile z racji nowej organizacji terytorialnej obejmującej terytorium diecezji wrocławskiej. Niezależnie od wszystkiego był to akt daleko idącej samowoli Hlonda, czego Stolica Apostolska z zasady nie tolerowała. Tak doszło do sporządzenia przez kardynała Hlonda

radość z przyłączenia (4 września 1939) Gdańska do Niemiec. Dnia 5 września tego roku wydał zakaz używania języka polskiego podczas nabożeństw. Na początku grudnia 1939 r. został administratorem diecezji chełmińskiej. W maju 1940 r. zakazał w obu diecezjach używania języka polskiego również podczas spowiedzi, choć sam spowiadał także po polsku. W marcu 1945 r. został aresztowany przez NKWD i więziony był przez półtora miesiąca w areszcie rosyjskim w Gdańsku. Zwolniony, podjął posługę w obu diecezjach. Ponownie aresztowany 9 sierpnia 1945 r., a 11 sierpnia tego roku otrzymał informację o zwolnieniu go z funkcji administratora diecezji chełmińskiej i biskupa gdańskiego. W procesie pokazowym w 1946 r. skazany został na 8 lat więzienia, utratę praw publicznych i obywatelskich oraz konfiskatę mienia. Karę odbywał we Wronkach k. Szamotuł, w Borku Starym (klasztor Dominikanów), Dukli (klasztor Bernardynów). Zwolniony w 1956 r. wyjechał do Niemiec. W roku następnym Stolica Apostolska powierzyła mu opiekę duszpasterską nad byłymi gdańszczanami mieszkającymi w Republice Federalnej Niemiec. Zmarł w Düsseldorfie. S. Bogdanowicz, Splett Karol Maria bp, w: Encyklopedia Katolicka, t. XVIII, Lublin 2013, kol. 687-688.

${ }_{11}$ Biskup Konrad von Preysing (1880-1950) - niemiecki duchowny katolicki, doktor teologii, kardynał. Pochodził z arystokratycznej rodziny. Święcenia kapłańskie przyjął 29 lipca 1912 r. w Innsbrucku. Dnia 9 września 1932 został biskupem diecezji Eichstätt. Na początku lipca 1935 r. objął stolicę biskupią w Berlinie, na której pozostał do śmierci. Dnia 18 lutego 1946 r. Pius XII wyniósł go do godności kardynalskiej.

12 J. KaPs, Bericht über die Reise eines schlesischen Priesters nach Rom zur Berichterstattung beim Heiligen Stuhl über die Verhältnisse in Breslau und Schlesien, „Archiv für Schlesische Kirchengeschichte“ 38 (1980); TENŻE, Vom Sterben schlesischer Prister 1945/46, München 1950. Kolejne wydanie: Vom Sterben Schlesischer Priester 1945/46, Köln 1990. 
dokumentu mającego usprawiedliwić podjęte przezeń działania. Dokument datowany 24 października 1945 r. liczył 40 stron ${ }^{13}$. Zredagowany był bardzo zręcznie, bowiem Hlond oświadczał, iż w świetle zastrzeżeń zgłoszonych z Rzymu zorientował się, iż mylnie zinterpretował uzyskane od papieża pełnomocnictwa i instrukcję Tardiniego, a jednocześnie przedstawiał sytuację na Ziemiach Odzyskanych i konieczność szybkiego działania w kierunku uchwycenia spraw kościelnych i niedopuszczenia do podejmowania w tej materii decyzji przez komunistów, co nastąpiłoby w przypadku pozostawienia niemieckiej administracji kościelnej. Raport Hlonda był rzeczowy i faktograficznie wiarygodny, co z pewnością bardzo osłabiło emocjonalne wywody Kapsa. Następny ruch należał do Stolicy Apostolskiej. Zwłaszcza dokonane przez kardynała Hlonda nowe podziały terytorialne Kościoła i utworzenie administracji apostolskich było z punktu widzenia kanonicznego takim nadużyciem, iż można było oczekiwać interwencji papieża. Takowa wszakże nie nastąpiła, co wskazywało na to, że Pius XII uznał dokonania Hlonda za celowe, a nawet konieczne, a Stolica Apostolska stanowisko swoje zaznaczała zapisem w „Annuario Pontificio” nieuwzględniającym dokonanych zmian, co było o tyle wygodne, że przecież należało odczekać na traktat pokojowy, który zresztą nigdy nie nastąpił.

Im bardziej utrwalał się stan Kościoła na dawnych ziemiach niemieckich, powstały z inicjatywy prymasa Hlonda, tym częściej pojawiać się zaczęły, właśnie ze strony Kościoła niemieckiego krytyczne interpretacje tego, co się tam dokonało, połączone z gwałtowną krytyką Hlonda. Zauważyć tu trzeba, że szło to w parze z opracowaniami na temat tzw. Vertreibung. Wysiedlenie Niemców z terenów przyznanych Polsce wiązało się, jako problem powojennych relacji między RFN a PRL - z NRD kształtowały się te stosunki na zasadzie wspólnej obecności w strefie wpływów sowieckich - z nieuznawaniem przez Niemcy Zachodnie prawa Polski do tych ziem, jak i tego, co określono tam jako Vertreibung. Na kanwie takich zapatrywań powstawała historiografia nacechowana irredentą. W połowie lat pięćdziesiątych inaugurowała ją edycja wspomnień spisywanych przez „wypędzonych”, konstruowanych według określonego kwestionariusza, co w rezultacie przedstawiało wysiedlenia jako czyn zbrodniczy i pozbawiony jakichkolwiek podstaw prawnych ${ }^{14}$.

13 Le cinque Ammistrazioni Apostoliche erecte in Polonia nell'agosto 1945. Wykorzystano tekst noszący adnotację: Teki Archiwalne „Acta Hlondiana” nr 9. August kard. Hlond, Prymas Polski. Materiały źródłowe, t. IX: Pisma, przemówienia, wypowiedzi. 1916-1948. Oryginały i kopie maszynowe. Ląd 1980. Źródło ma postać skserowanego maszynopisu.

14 Gromadzenie świadectw osób wysiedlonych z dawnych terenów niemieckich przyznanych w 1945 r. Polsce zaczęło się w RFN w początkach lat pięćdziesiątych ubiegłego wieku. Chodziło bowiem o uchwycenie jak największej liczby bezpośrednio dotkniętych wysiedleniem. W ten sposób pojawiła się bogata literatura wspomnieniowa. Pracą tą kierował od 1952 r. prof. Theodor von Schie- 
Rzecz jasna, że aktywność polskiego Prymasa zaszeregowana została do rzędu napiętnowanych aktów bezprawia i potraktowana w kategoriach moralnych ${ }^{15}$. Podobnych do tej publikacji ukazywało się sukcesywnie znacznie więcej, częściowo zresztą pióra tego samego autora. Ich cechą charakterystyczną było odejście od realiów historycznych i skupienie się na konstrukcjach myślowych, opartych na przesłankach moralnych i sztucznie tworzonych argumentacjach prawnych. Kardynał August Hlond przedstawiany jest jako polski szowinista współdziałający z władzami komunistycznymi. To spychanie poza margines historyczny ocen tego, co dokonało się na ziemiach utraconych przez Niemcy na rzecz Polski, napotykało krytykę niektórych historyków niemieckich ${ }^{16}$, ale i oni nie rezygnowali z podkreślania moralnych aspektów towarzyszących zagospodarowywaniu ziem poniemieckich także w wymiarze kościelnym. Niektórzy autorzy niemieccy posuwali się aż do inwektyw aplikowanych Hlondowi w związku z perspektywą jego beatyfikacji ${ }^{17}$. Tak radykalne potępienie Hlonda wśród katolików niemieckich należy do wyjątków, natomiast powszechne jest zdanie, że Hlond zniszczył niemiecki Kościół na wschodzie i pośrednio przyczynił się do cierpień tamtejszej ludności niemieckiej.

Ocena tego, co prymas August Hlond uczynił na tzw. Ziemiach Odzyskanych, musi mieć na względzie sytuację, w jakiej znalazł się zarówno on, jak i Polska. Po-

der (1908-1984), były nazista, ale także uczeń profesora Hansa Rothfelsa (1891-1976) z Królewca, bodajże jedynego Żyda, którego pozostawiono na katedrze uniwersyteckiej. Jego staraniem ukazały się m.in.: Dokumentation der Vertreibung der Deutschen aus Ost-Mitteleuropa, t. I: Die Vertreibung der deutschen Bevölkerung aus den Gebieten Östlich der Oder-Neisse, bearbeitet von Th. Schieder, Bonn 1954, cz. 1-2; 1 Beiheft: Ein Tegebuch aus Pommern 1945-1946, München 1955; Die deutschen Vertreibungsversluste, Bevölkerungsbilanzen für die deutschen Vertreibungsgebiete 1939-1945, Stuttgart 1958; Dokumente deutscher Kriegsschäden: Evakuierte, Kriegssachgeschädigte, Währungsgeschädigte. Die geschichtliche und rechtliche Entwicklung, Bonn 1958, 5 tomów. Die Tragödie Schlesiens 1945-46 in Dokumenten, München 1955.

15 F. Scholz, Zwischen Staatsräson und Evangelium. Kardinal Hlond und die Tragödie der ostdeutschen Diözesen, Frankfurt am Main 1988.

16 H.-J. KARP, Kardinal Hlond und das schwierige deutsch-polnische Verhältnis. Zu den Anfragen vom Franz Scholz, „Zeitschrift für Geschichte und Altertumskunde Ermlands“ 45 (1989), s. 145-164.

17 Przykładowo warto zwrócić uwagę na publikację jezuity o. Lothara Groppe, Kardinal Hlond als seeliger?, „Theologisches” 27 (1997) 3, s. 83-88; TENŻE, Empfielt sich Kardinal Augustyn [sic!] Hlond als Kandidat einer Seeligsprechung?, „Theologisches” 27 (1997) 7/8, s. 302-306.

Jako problem, w świadomości polskiej wysiedlenie Niemców pojawiło się dopiero od 19891990 r. Do tego czasu władze partyjno-rządowe Polski Ludowej uważały „zagadnienie niemieckie” na ziemiach polskich za temat ostatecznie zamknięty, a więc nieaktualny. Odmienny punkt widzenia przedstawiała strona niemiecka. 
zostawienie niemieckiej administracji kościelnej na tych ziemiach musiałoby doprowadzić do przejęcia pełnej inicjatywy na polu kościelnym przez komunistyczne władze. W dalszej perspektywie było powstanie obszaru, jeśli nie całkowicie wolnego od wpływów kościelnych, to ograniczonych do postaci sterowanej i wykorzystanej przez ową władzę. W pewnym sensie byłaby to pustynia wyznaniowa i poletko doświadczalne dla tworzenia społeczności bezwyznaniowej.

Inicjatywy Hlonda zapobiegły temu. To, czy postąpił świadomie, poszerzając otrzymane pełnomocnictwa Stolicy Apostolskiej, czy też po swojemu je zrozumiał lub zinterpretował, nie znajdzie nigdy jednoznacznej odpowiedzi. Przypuszczenie daje priorytet pierwszej ewentualności; a więc felix culpa? Dla Watykanu postępowanie Hlonda, jak się szybko okazało, było wygodnym rozwiązaniem, a przede wszystkim ratującym katolicyzm w jednym z państw bloku sowieckiego. Hlond zatem nigdy nie został zdezawuowany przez Stolicę Apostolską. Co więcej, w 1950 r., kiedy prymas Stefan Wyszyński, ratując Kościół w Polsce przed grożącą mu schizmą, mianował swoimi wikariuszami generalnymi narzuconych Administracjom Apostolskim na Ziemiach Zachodnich i Północnych przez rząd administratorów, Watykan także nie podjął żadnych kroków w kierunku cofnięcia regulacji wprowadzonych tam przez kardynała Hlonda. Jego dokonania zatem zaowocowały w następnych dziesiątkach lat sfinalizowaniem w postaci w pełni zorganizowanych i kanonicznie umocowanych obszarów kościelnych w bloku sowieckim. W tzw. demoludach był to precedens i bodajże jedyny taki przypadek.

\section{BIBLIOGRAFIA}

Bogdanowicz S., Splett Karol Maria bp, w: Encyklopedia Katolicka, t. XVIII, Lublin: TN KUL 2013, kol. 687-688.

Casula C.F., Domenico Tardini 1888-1961, Roma: Edizione Studium Roma 1988.

Dokumentation der Vertreibung der Deutschen aus Ost-Mitteleuropa, t. I: Die Vertreibung der deutschen Bevölkerung aus den Gebieten Östlich der Oder-Neisse, bearbeitet von Th. Schieder, Bonn: Bundesministerium für Vertriebene 1954.

Gigilewicz E., Kaller Maxymilian bp, w: Encyklopedia Katolicka, t. XVIII, Lublin: TN KUL 2000, kol. 406-407.

GropPe L., Kardinal Hlond als seeliger?, „Theologisches” 27 (1997) 3, s. 83-88.

Groppe L., Empfielt sich Kardinal Augustyn [sic!] Hlond als Kandidat einer Seeligsprechung?, „Theologisches” 27 (1997) 7/8, s. 302-306.

KAPS J., Bericht über die Reise eines schlesischen Priesters nach Rom zur Berichterstattung beim Heiligen Stuhl über die Verhältnisse in Breslau und Schlesien, „Archiv für Schlesische Kirchengeschichte“ 38 (1980).

Kaps J., Vom Sterben Schlesischer Priester 1945/46, Köln: Wienand Verlag Köln 1990. 
KARP H.-J., Kardinal Hlond und das schwierige deutsch-polnische Verhältnis. Zu den Anfragen vom Franz Scholz, „Zeitschrift für Geschichte und Altertumskunde Ermlands“ 45 (1989), s. 145-164.

Kumor B., Historia Kościoła, część 8: Czasy współczesne 1914-1992, Lublin: Wydawnictwo KUL 1996.

Scholz F., Zwischen Staatsräson und Evangelium. Kardinal Hlond und die Tragödie der ostdeutschen Diözesen, Frankfurt am Main: Knecht 1988.

SNOCH B., Górnośląski leksykon biograficzny. Suplement do wydania drugiego, Katowice: Muzeum Śląskie 2006, s. 89.

ZIELIŃSKI Z., Papieże i papiestwo dwóch ostatnich wieków 1775-1978, Warszawa: Instytut Wydawniczy Pax 1983.

\section{„FELIX CULPA” PRYMASA POLSKI AUGUSTA HLONDA?}

\section{Streszczenie}

Zmiana granicy państwa polskiego po II wojnie światowej i proces przesiedlania ludności z Kresów Wschodnich do Polskiej Rzeczypospolitej Ludowej stworzyły swoisty tygiel ludnościowy na Ziemiach Zachodnich i Północnych, na które przybywały transporty z Kresów Wschodnich, z Polski centralnej i Małopolski oraz emigranci z państw zachodnich. Na tych ziemiach opuszczonych przez Niemców, największego znaczenia nabierały kształtujące się stosunki ludnościowe i religijne. W powojennych warunkach procesy integracyjne na tych terenach następowały powoli, w czym nie do przecenienia miało wpływ ustanowienie organizacji polskiej administracji kościelnej oraz praca pastoralna polskiego duchowieństwa katolickiego.

Prymas Polski kard. August Hlond powrócił do Polski 20 lipca 1945 r., w momencie, kiedy miały się decydować losy granic państwa, ustroju, a przede wszystkim tak mocno poszczerbionego przez wojnę i okupację Kościoła. Podejmowane przez komunistów reformy motywowane frazeologią demokratyczną, w rzeczywistości były budową demokracji socjalistycznej. Kościół w tamtym czasie ucierpiał wskutek reformy rolnej, a znaczącym ostrzeżeniem było wypowiedzenie dnia 12 września 1945 r. przez komunistów konkordatu. Na skutek izolacji Polski w stosunku do Zachodu, kardynał Hlond uważał za konieczne podejmowanie decyzji bez współdziałania ze Stolicą Apostolską, aby na terenach Ziem Odzyskanych z napływową ludnością polską zapewnić polską organizację i hierarchę kościelną, gdyż na podstawie dotychczasowych doświadczeń z Niemcami jasne dla niego było, iż na ziemiach poniemieckich nie może ostać się niemiecka administracja kościelna. Ponadto sądził, że tymi działaniami organizacyjno-prawnymi uniemożliwiał komunistycznemu rządowi stworzenie obszarów wyjętych spod wpływu Kościoła, albo dopuszczenie wprawdzie polskiej organizacji kościelnej, ale całkowicie sobie podporządkowanej, czego próby podejmowano w $1950 \mathrm{r}$.

Zaprowadzenie hierarchii polskiej w miejsce niemieckiej było postrzegane w Niemczech i częściowo w Watykanie jako bezprawie już w 1945 r. W związku z powyższym kardynał Hlond w dokumencie z 24 października 1945 r. (40 stron) do Rzymu, usprawiedliwiającym podjęte przezeń działania oświadczał, iż w świetle zastrzeżeń z Rzymu zorientował się, iż mylnie 
zinterpretował uzyskane od papieża pełnomocnictwa i instrukcję Tardiniego. Jako kontrargument opisał sytuację na Ziemiach Odzyskanych i konieczność szybkiego działania w sprawach kościelnych i niedopuszczenie do podejmowania w tej materii decyzji przez komunistów, co nastąpiłoby w przypadku pozostawienia niemieckiej administracji kościelnej. Raport Hlonda do Rzymu był rzeczowy i faktograficznie wiarygodny, a dokonane przez niego podziały terytorialne Kościoła i utworzenie administracji apostolskich, nie tylko nie spowodowały interwencji papieża, a - jak się wkrótce okazało - dla Watykanu postępowanie Hlonda było wygodnym rozwiązaniem, ratującym katolicyzm w jednym z państw bloku sowieckiego, za co kardynał nigdy nie został zdezawuowany przez Stolicę Apostolską.

Proces beatyfikacyjny Augusta Hlonda rozpoczął się w 1992 r. Na szczeblu diecezjalnym zakończył się w 1996 r. Przeciwny jego beatyfikacji był Związek Wypędzonych i episkopat niemiecki. Opracowane w 2008 r. Positio, Komisja Teologiczna Kongregacji Spraw Kanonizacyjnych zaopiniowała w 2017 r. pozytywnie. W 2018 r. uczynili to kardynałowie i biskupi z Kongregacji Spraw Kanonizacyjnych. Dnia 19 maja 2018 r. papież Franciszek podpisał dekret o heroiczności cnót kard. Hlonda. Przysługuje mu odtąd tytuł Czcigodnego Sługi Bożego.

Słowa kluczowe: prymas Polski kardynał August Hlond; hierarchia kościelna w Polsce w drugiej połowie XX wieku na Ziemiach Odzyskanych; historia Kościoła w Polsce w XX i XXI wieku

\section{„FELIX CULPA” OF PRIMATE OF POLAND AUGUST HLOND?}

\section{Sum mary}

The change of the border of Poland after the Second World War and the process of the relocation of Poles to the newly established Polish People's Republic created a kind of melting pot in the Western and Northern Territories, in which transports arrived from the Eastern Borderlands, Central Poland and Little Poland, as well as from Western countries. In these lands abandoned by Germans, it was the emerging population and religious issues that had the greatest importance. In the post-war reality, the integration process was rather slow in these areas, but it must be noted that the establishment of the organization of the Polish church administration and the pastoral work of the Polish Catholic clergy were invaluable in this matter.

After the war, Primate of Poland August Hlond returned to Poland on 20 July 1945, at a time when the fate of the state borders, of the system and, above all, of the Church, so severely afflicted by the war and occupation, was to be decided. The post-war reforms, which were introduced by communists and justified by democratic phraseology, were aimed at building socialist democracy. The church at that time suffered due to implementing land reform. Another clear warning was the annulment of the concordat by communists on 12 September 1945. As a result of Poland's isolation from the West, Cardinal Hlond considered it necessary to make decisions about establishing Polish organization and the church hierarchy in the Regained Territories without cooperation with the Holy See. He thought that the German church administration could not be maintained in the former German lands. Moreover, he believed that these organizational and 
legal actions would prevent the communist government from creating areas without the influence of the Church, or from establishing Polish church organization completely dependent on communists, which was attempted in 1950.

The establishment of the Polish hierarchy in place of the German was seen as lawless in Germany and partly in the Vatican as early as 1945. On 24 October 1945 Cardinal Hlond sent the document (40 pages) to Rome justifying his actions. He stated that seeing the objections expressed by Rome, he realized that he had misinterpreted the powers and instructions of Tardini obtained from the Pope. As a counter-argument, he described the situation in the Recovered Territories and explained that he had had to act quickly in church matters in order to prevent communists from making decisions in this matter, which would have happened if the German church administration had remained. Hlond's report to Rome was factually credible, and his territorial divisions of the Church and the establishment of the apostolic administrations did not invoke the Pope's intervention. Soon it transpired that Hlond's actions were convenient for the Vatican, and thus he saved Catholicism in one of the countries of the Soviet Bloc. That is why Hlond was never disapproved by the Holy See for what he had done.

August Hlond's beatification process began in 1992. It ended in 1996 at the diocesan level. The Federation of Expellees and the German episcopate were against Hlond's beatification. In 2017, the Theological Commission of the Congregation for the Causes of Saints gave a positive opinion about the Positio of 2008. In 2018, the same was done by the cardinals and bishops of the Congregation for the Causes of Saints. On 19 May 2018, Pope Francis signed a decree on the heroic virtues of Cardinal Hlond. Since then he has had the title of the Venerable Servant of God.

Keywords: Primate of Poland August Hlond; the church hierarchy in Poland the second half of the $20^{\text {th }}$ century in the Regained Territories; the history of the Church in the $20^{\text {th }}$ and $21^{\text {st }}$ centuries 